\title{
Corporate Social Responsibility of Private Banks in Bangladesh: Expectations, Achievements and Challenges
}

\author{
Md. Fouad Hossain Sarker \\ Lecturer \\ Faculty of Science \& Information Technology \\ Daffodil International University \\ Dhaka-1207, Bangladesh \\ Tel: +88 $01554336014 \quad$ E-mail: fouadsarker@yahoo.com
}

Received: February 27, 2012 Accepted: April 16, 2012 DOI: 10.5296/jpag.v2i1.1583

\begin{abstract}
This paper examines people's understanding, expectations and assessment of the corporate social responsibility (CSR) of private banks, especially Dutch-Bangla Bank Ltd. (DBBL), one of the largest private banks in Bangladesh. This study has been conducted among the stakeholders and beneficiaries of the Dutch Bangla Bank Limited. Surveys have been conducted using structured questionnaires to critically examine the subjective perceptions of the meaning, reasons and various aspects of CSR tasks of DBBL in Bangladesh. It has been found out that common people either do not have clear understanding about CSR activities or are not really concerned about the social responsibilities of the corporate organizations. The expected outcome of CSR activities, as has been stated in the memorandum and commitments of the corporate houses, has yet to be achieved. This study suggests that a more comprehensive and humane involvement of the common people in the CSR activities is required, which would not only fulfill the intended goals and objectives of the corporate organizations but also ensure a successful and sustainable development of the society.
\end{abstract}

Key words: Corporate social responsibility, Dutch-Bangla Bank Limited, Bangladesh. 


\section{Introduction}

Corporate organizations are playing an important role in social development through sharing their profit for many benevolent and philanthropic activities under the rubric of Corporate Social Responsibility (CSR). CSR has become a common word highly discussed and prioritized by the national and international organizations, development sectors, professionals and scholars, and global business partners. Generally, social responsibility means the works which will bring about the overall betterment of the mass people in the society. In this context, CSR concept has a promising humane future as it addresses and captures the most important concerns of the public regarding business and society relationships (Carroll 1999). Business in a capitalistic world is all about making profits. CSR, however, challenges such corporate attitude and push them to be more humanistic and oblige them not to forget the social responsibilities to fighting many odds at the societal level. As every person has his own social responsibilities towards the society so does the business firms. Business is an inseparable and embedded part of the society (Alam et al. 2010). Besides conducting business activities and pursuing economic gains, business houses also have several other roles and responsibilities towards society such as the social and environmental responsibilities and business contributions that would benefit the society at large (Preston and Post 1975; Davis and Blomstrom 1971; Margolis and Walsh 2001; Sethi 1975). It is mandatory for companies to conform to the legal responsibilities as prescribed by law. So, organizations have no alternative but to comply with the basic law of the land (Carrol 1979). The idea is that, above and beyond making a profit, the business has social obligations that must be carried out through corporate social responsibility.

It has been generally accepted that corporate social responsibility is an inevitable matter which was adopted globally to ensure sound development of the world. Sustainable development is not possible without evenhanded support of corporate world. Hence, corporate society has a linchpin role to open up a lion share opportunity in every pros and cons of any society. It is regretful, however, that although CSR activities are forcefully implemented internationally, Bangladesh is still lagging behind. Although Dutch-Bangla Bank Limited in Bangladesh is a pioneer organization which is contributing to ensure its social responsibility from the beginning to present day, suspicions prevails that they depart from the spirit of the concept of 'CSR' today. To them, it is a business tool or policy or an advertisement which ensures maximum productivity, reorganizations, benefits and other facilities of their organizations. Keeping mind all these deliberations, this study tries to explore: (I) what people actually think about the CSR activities, (II) subjective perceptions about various CSR tasks of DBBL, (III) objectives of CSR activities and its outcomes, and (IV) how DBBL can enrich its CSR activities by incorporating other sectors in its current CSR policy.

\section{Methodology of the Study}

In order to achieve the objectives of this study both qualitative and quantitative research methods have been used. Data from both primary and secondary sources were collected. 
Secondary sources include reports, documents, magazines, books, journals, various newspapers, and subject related websites and research documents. Literature review covered various issues such as definition and nature of corporate social responsibility, business ethics, organizational mission and vision, various social and environmental responsibilities and sustainable development, respect for human rights, health and professional safety in Bangladesh. Primary data were collected through conducting surveys from the target respondents such as beneficiary groups and different stakeholders of DBBL. A total of 105 respondents were interviewed using structured questionnaire who selected through random sampling.

\section{Conceptualizing Corporate Social Responsibility}

The concept of CSR has had a long and diverse history in the literature (Carroll 1999). It came into a common use in the late 1960s and early 1970s as many multinational corporations were formed that time. In the beginning, it refers to the obligations of businessmen to pursue those policies, to make those decisions, or to follow those lines of actions which are desirable in terms of objectives and values of our society (Bowen 1953). After 1960s, the literature on CSR developed considerably and that time it defined as the new concept of social responsibility which recognizes the intimacy of the relationships between the corporation and the society, and realizes that such relationships must be kept in mind by the top managers as the corporation and the related groups pursue their respective goals (Walton 1967). In its broadest sense, corporate social responsibility represents a concern with the needs and goals of society which goes beyond the merely economic one. Recently corporate social responsibility movement represents a board concern with business's role in supporting and improving the social order (Eells \& Walton 1974). Social responsibility usually refers to the objectives or motives that should be given weight by the business in addition to those dealing with economic performance (e.g., profits). Backman (1975) identified CSR activities as: "employment of minority groups, reduction of pollution, greater participation in programs to improve the community, improved medical care, improved industrial health and safety-these and other programs designed to improve the quality of life are covered by the board umbrella of social responsibility" (Backman 1975).

In 1980 Thomas M. Jones entered the CRS discussion with an interesting perspective. He defined corporate social responsibility as "the notion that corporations have an obligation to constituent groups in society other then stockholders and beyond that prescribed by law and union contract" (Jones 1980). Two facts of this definition are crucial. First, the obligation must be voluntarily adopted; behavior influenced by the coercive forces of law or union contract is not voluntary. Secondly, the obligation is a broad one, extending beyond the traditional duty to shareholders to other societal groups such as customers, employees, suppliers, and neighboring communities. Moreover, "corporate social responsibility relates primarily to achieving outcomes from organizational decisions concerning specific issues or problems which (by some normative standard) have beneficial rather than adverse affects on pertinent corporate stakeholders" (Epstein 1983: 104). The term stakeholder, meaning those on whom an organization's activities have an impact, was used to describe corporate owners 
beyond shareholders as a result of an influential book by R. Edward Freeman, Strategic management: a stakeholder approach in 1984 (Bansal \& Roth 2000). Proponents argue that corporations make more long term profits by operating with a perspective, while critics argue that CSR distracts from the economic role of businesses. Others argue CSR is merely window-dressing, or an attempt to preempt the role of government as a watchdog over powerful multinational corporations. Some other studies have found out that anything imposed from the top on the organizations without any real commitment from inside often doomed to failure, as has been demonstrated in the microcredit programme of non-governmental organizations in Bangladesh (Saiful 2004; 2010).

Corporate social responsibility (CSR), which is also variably called as corporate conscience, corporate citizenship, social performance, or sustainable responsible business (Wood 1991), is a form of corporate self-regulation integrated into a business model. The goal of CSR is to embrace responsibility for the company's actions and encourage a positive impact through its activities on the environment, consumers, employees, communities, stakeholders and all other members of the public sphere. Furthermore, CSR-focused businesses would proactively promote the public interest by encouraging community growth and development, and voluntarily eliminating practices that harm the public sphere, regardless of legality. Finally, Corporate Social Responsibility is an effective way of functioning on particular issues relating to responsibility for looking after relations with all interested parties and working towards long-term sustainable development.

\section{An Overview of CSR Activities of DBBL}

Dutch-Bangla Bank Ltd., a leading and first joint venture bank which operated in Bangladesh by local shareholders spearheaded by the leadership of founder chairman, M Sahabuddin Ahmed. It was established under the Bank Companies Act 1991 and incorporated as a public limited company under the Companies Act 1994 in Bangladesh with the primary objective to carry on all kinds of banking business in Bangladesh. DBBL commenced formal operation from June 3, 1996. The Bank is listed with the Dhaka Stock Exchange Limited and Chittagong Stock Exchange Limited. From the onset, the focus of the bank has been financing high-growth manufacturing industries in Bangladesh. The rationale being that the manufacturing sector exports Bangladeshi products worldwide. Thereby financing and concentrating on this sector allows Bangladesh to achieve the desired growth. Along with business, Dutch Bangla Bank Limited focuses on corporate social responsibility (CSR) under the supervision of DBBL foundation which established in June 2001, which carries out humanitarian activities like rehabilitation of the destitute and neglected section of the society. DBBL provides 5 percent of its gross profit to the foundation every year (Bangladesh Bank 2010 p 35). Even though CSR is now a cliché, DBBL is the pioneer in this sector and termed the contribution simply as "social responsibility". Due to its investment in this sector, DBBL has become one of the largest donors and the largest bank donor in Bangladesh. CSR expenditures of Dutch Bangla Bank Limited in various years as follows: 


\begin{tabular}{|l|l|l|l|}
\hline SL. & Years & $\begin{array}{l}\text { CSR expenditures of Dutch } \\
\text { Bangla Bank Limited } \\
\text { (Million Taka) }\end{array}$ & $\begin{array}{l}\text { Total CSR expenditure } \\
\text { of 46 Scheduled Banks } \\
\text { (Million Taka) }\end{array}$ \\
\hline 1 & 2009 & 159.20 & 553.8 \\
\hline 2 & 2008 & 171.01 & 410.7 \\
\hline 3 & 2007 & 39.20 & 226.4 \\
\hline
\end{tabular}

Table 1: Review of Corporate Social Responsibility (CSR) Initiatives of Banks in Bangladesh, (2008 \& 2009)

Recently a number of sectors such as education, healthcare, human resource development, conservation of nature, creation of social awareness, rehabilitation of destitute people are incorporated into the bank's social and philanthropic activities (DBBL 2010). Figure-1 illustrates the contribution of DBBL to different sectors in 2010. According to the following figure, 50.16 million taka has been disbursed for the education purpose whereas another 5 million taka for culture \& sports. On the other hand, 30.75, 27.02 and 12.5 million taka have been used for miscellaneous, health and disaster sector respectively.

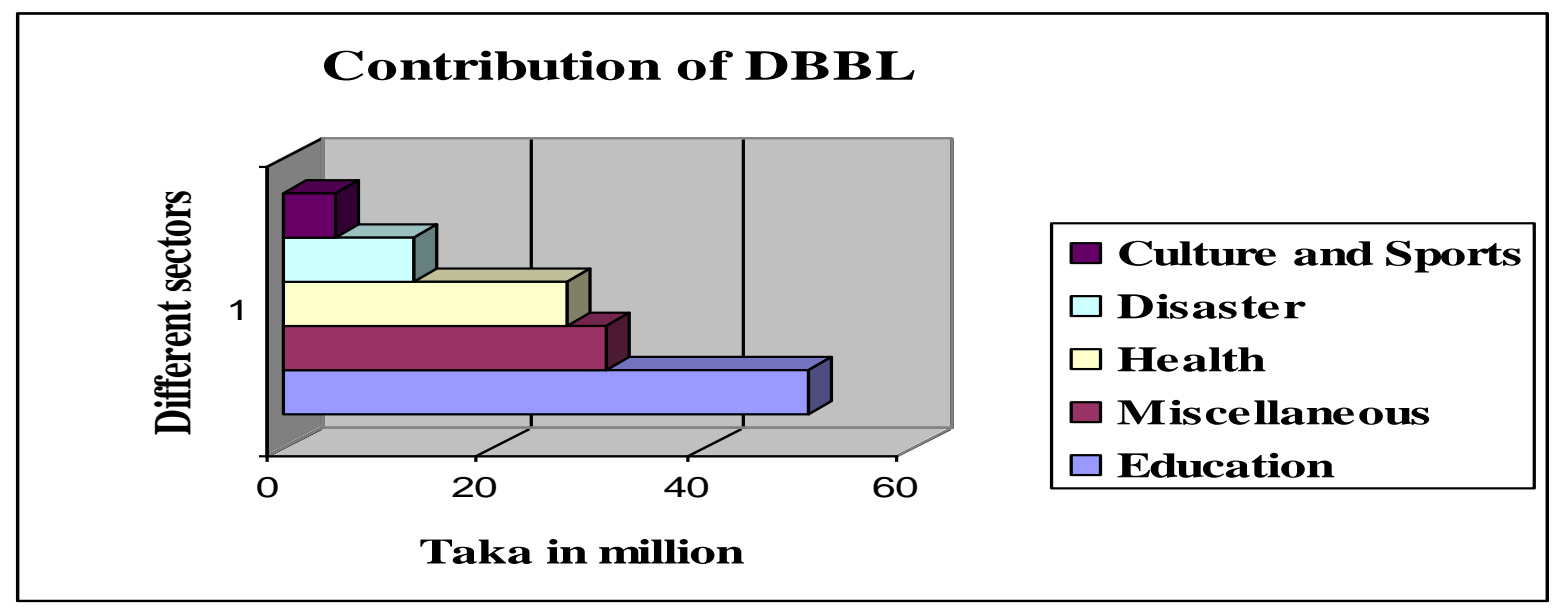

Figure-1: Contribution of DBBL to Different Sectors in 2010

DBBL is the first bank in Bangladesh which is fully automated to serve its clients. The Electronic-Banking Division was established in 2002 to undertake rapid automation and bring modern banking services into this field. Full automation was completed in 2003 and was introduced plastic money to the Bangladeshi masses. DBBL also operates the nation's largest ATM fleet and in the process drastically cut consumer costs and fees by $80 \%$. Moreover, DBBL has pursued the mass automation in Banking as a CSR activity and never intended profitability from this sector. As a result it now provides unrivaled banking technology offerings to all its customers. The bank has won numerous international awards 
because of its unique approach as a socially conscious bank. For example, Dutch-Bangla Bank Limited has won Asian CSR Award-2005 for its outstanding program on Corporate Social Responsibility (CSR). Mr. Yeasin Ali, Managing Director, DBBL is seen receiving Asian CSR Award-2005 from the Chief Guest, Dr. Juwono Sundarsono, the Honorable Minister for Defense, the Republic of Indonesia at a ceremony held on September 09, 2005 in Jakarta (MjB 14).

\section{Data Analysis and Findings of the Study}

This section analyzes data collected from respondents regarding their perceptions and understanding about the impacts of corporate social responsibility on sustainable development. The survey reveals that $78 \%$ of the respondents are male whereas only $22 \%$ are female. Among the male respondents, $42 \%$ are married while $36 \%$ are unmarried. Among the female respondents, about $12 \%$ are married whereas $10 \%$ remains unmarried. Majority of respondents belong to the age group 25-30 and 20-25 years. On the other hand, only a very few $(8.46 \%)$ respondents belong to the age group 35-40 and 40-45, whereas $45+$ age group constitutes $4.62 \%$ of the respondents. It means that most respondents are in the youth group. Educational status of the respondents' shows that most of the respondents are university graduates. Only a very few of them $(2.30 \%)$ passed secondary educational level. It means that most of respondents are well educated. The occupational status of the respondents reveals that majority of the respondents $(40.77 \%)$ are service holders where as $(21.54 \%)$ are students respectively. On the other hand, a few number of them are businessmen with $(8.46 \%)$, bankers with $(7.69 \%)$ respectively. The survey further reveals that the majority of the respondents are Muslims while about (8\%) are Hindus and others.

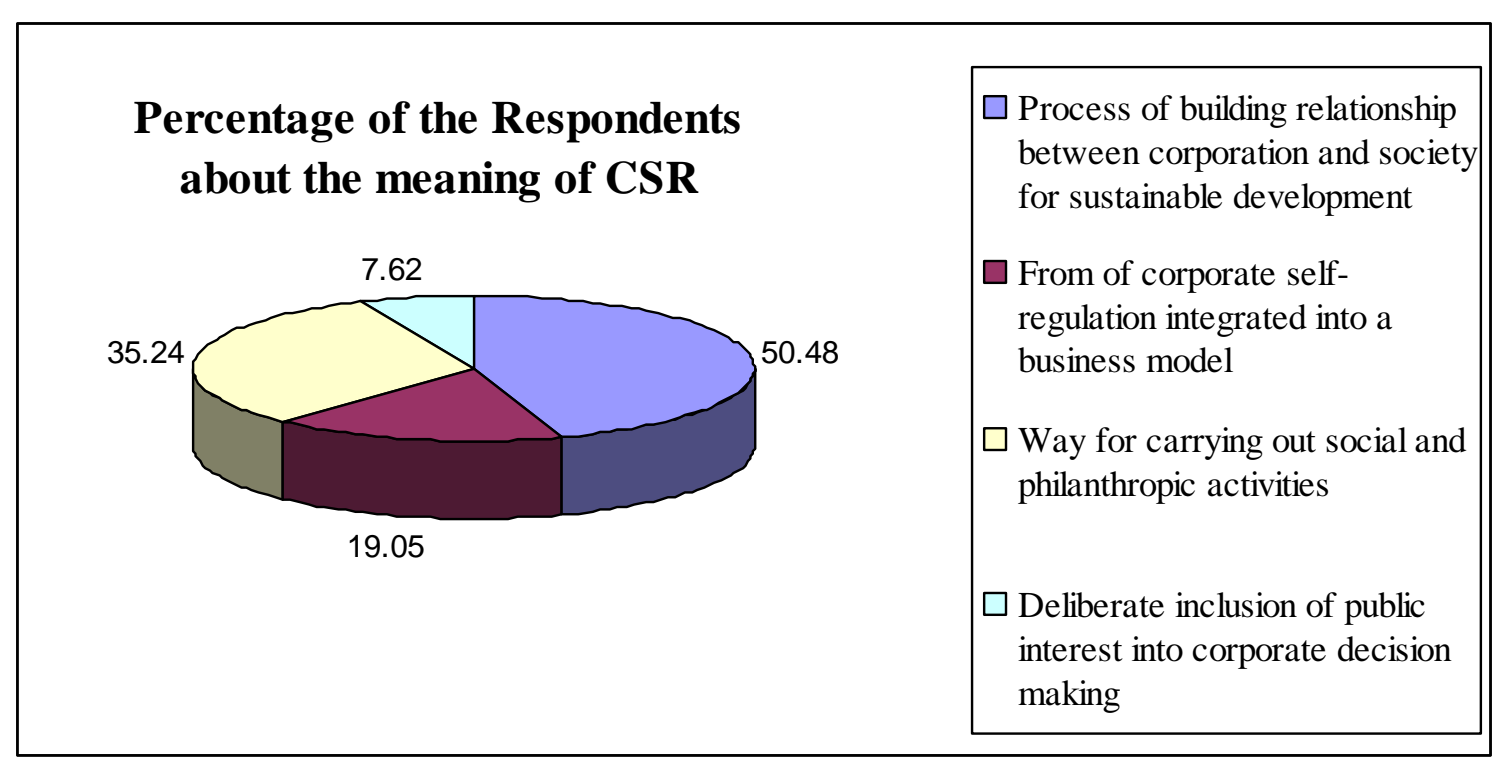

Figure-2: Perceptions about Corporate Social Responsibility 
It has been observed from this survey that $81 \%$ of the respondents have sufficient knowledge about corporate social responsibility of Dutch Bangla Bank Limited in Bangladesh, whereas $19 \%$ said that they have no idea about corporate social responsibility. Figure-2 reveals people's perception about corporate social responsibility. Most respondents describe corporate social responsibility as the process of building relationship between corporation and society for sustainable development whereas only $7.62 \%$ of the respondents know that they have the opportunity to be included into corporate decision making process. On the contrary, $35.24 \%$ refer to corporate social responsibility means way for carrying out social and philanthropic activities while about $19 \%$ refer to form of corporate self-regulation integrated into business model.

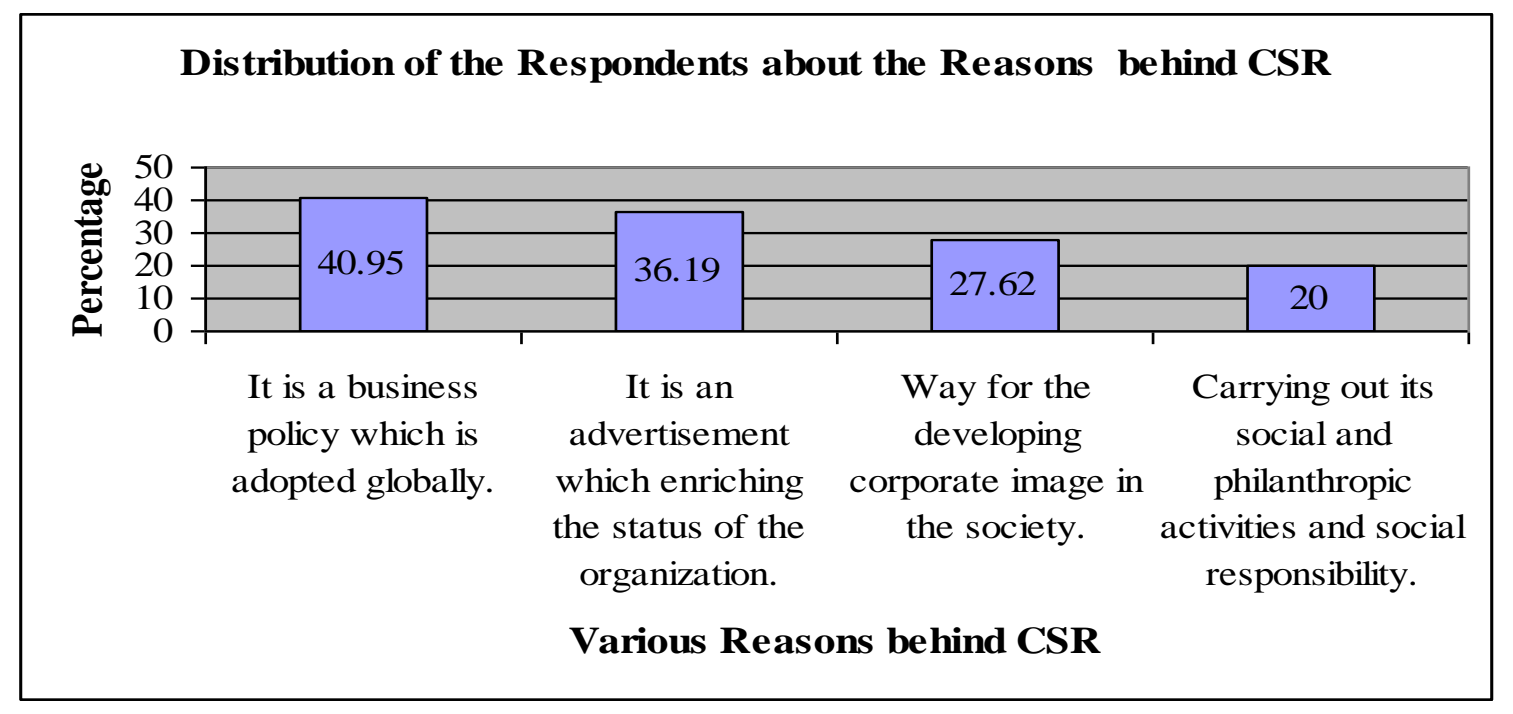

\section{Figure-3: Reasons behind CSR tasks by Dutch Bangla Bank Limited}

Figure-3 demonstrates the reasons for the development of CSR tasks by Dutch Bangla Bank Limited in Bangladesh. From this survey, it has been found out that most respondents consider CSR tasks of DBBL to be a business policy which adopted globally, whereas about $36 \%$ of respondents believe that CSR activities are merely an advertisement to promoting the status of the organization. On the other hand, $28 \%$ respondents agreed that through CSR activities this organization promotes corporate image in the society, whereas another $20 \%$ consider carrying out its social and philanthropic activities and social responsibility. It means that only a small number of respondents actually know the overall objectives of CSR of DBBL. Recently Dutch Bangla Bank Limited is working in various fields of CSR in Bangladesh. It has been observed from figure-4 that most respondents (78.09\%) know the CSR activities of DBBL are in the fields of facilitating education and social awareness building, whereas about $41 \%$ knows development of health and safety sectors. On the contrary, $35.27 \%$ respondents replied that DBBL works in the field of environment and disaster management while $20 \%$ refer to development of infrastructure and sports sectors. 


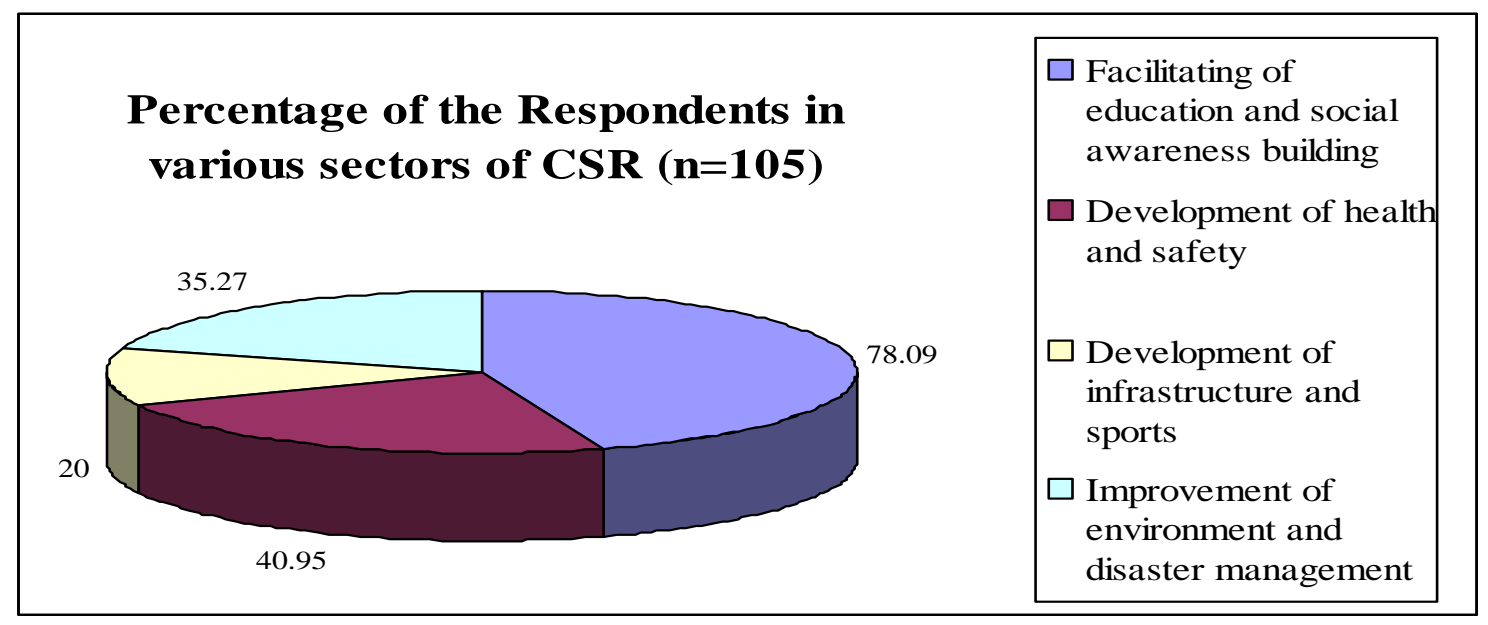

Figure-4: Perception in various CSR tasks of Dutch Bangla Bank Limited

In education sector, the perception of public is positive. It is revealed from this study that $50.48 \%$ believe that the contribution of Dutch Bangla Bank Limited is "Good" where as about $28 \%$ consider it as "Average". A few of them stated "Very Poor" (2.86\%) and 'Poor' $(10.48 \%)$ and "Outstanding" (8.57\%) respectively. Most respondents (42\%) do not consider social awareness building is good enough. Whereas 30\% respondents said CSR is "Good" $15 \%$ respondents responses says "Poor" whereas only $7 \%$, a small segment of respondents consider as it 'Outstanding'.

\section{Distribution of the Respondents in Environment and Disaster Management Sector}

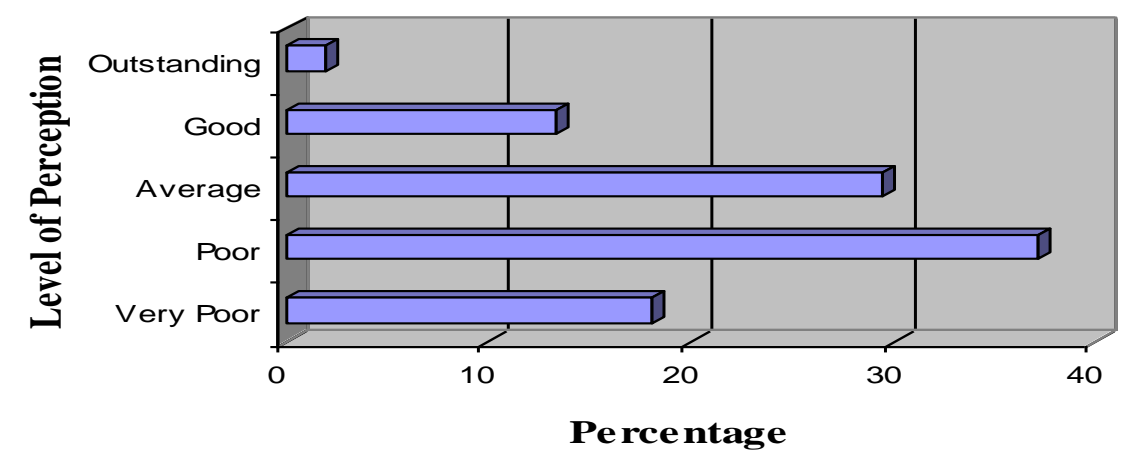

Figure-5: Perception in environment and disaster management sector

It has also been observed from this survey that the involvement of Dutch Bangla Bank Limited in promoting health and safety sector in Bangladesh is not positive enough. Most respondents (43\%) perceive it as "Average" whereas $24.76 \%$ respondents explained it as 


\section{Macrothink}

"Poor". Only 3.81\% replied that the involvement of DBBL in health sector is outstanding. On the other hand, in infrastructure and sports sectors, the perception of respondents is a bit negative. This survey discloses that $38.09 \%$ respondents regard the infrastructure and sports sectors involvement of Dutch Bangla Bank Limited is 'Poor' whereas about $32.38 \%$ consider it as "Average" and only a few respondents (3.81\%) found it to be "Outstanding". In facilitating environment and disaster management sector, the observation of respondents is almost negative. Figure-5 shows that majority of respondents $(37.14 \%)$ believe that the contribution of Dutch Bangla Bank Limited in environment and disaster management sector is "Poor" whereas $18.09 \%$ consider it to be "Very poor" and only $1.90 \%$ respondents think it as "Outstanding".

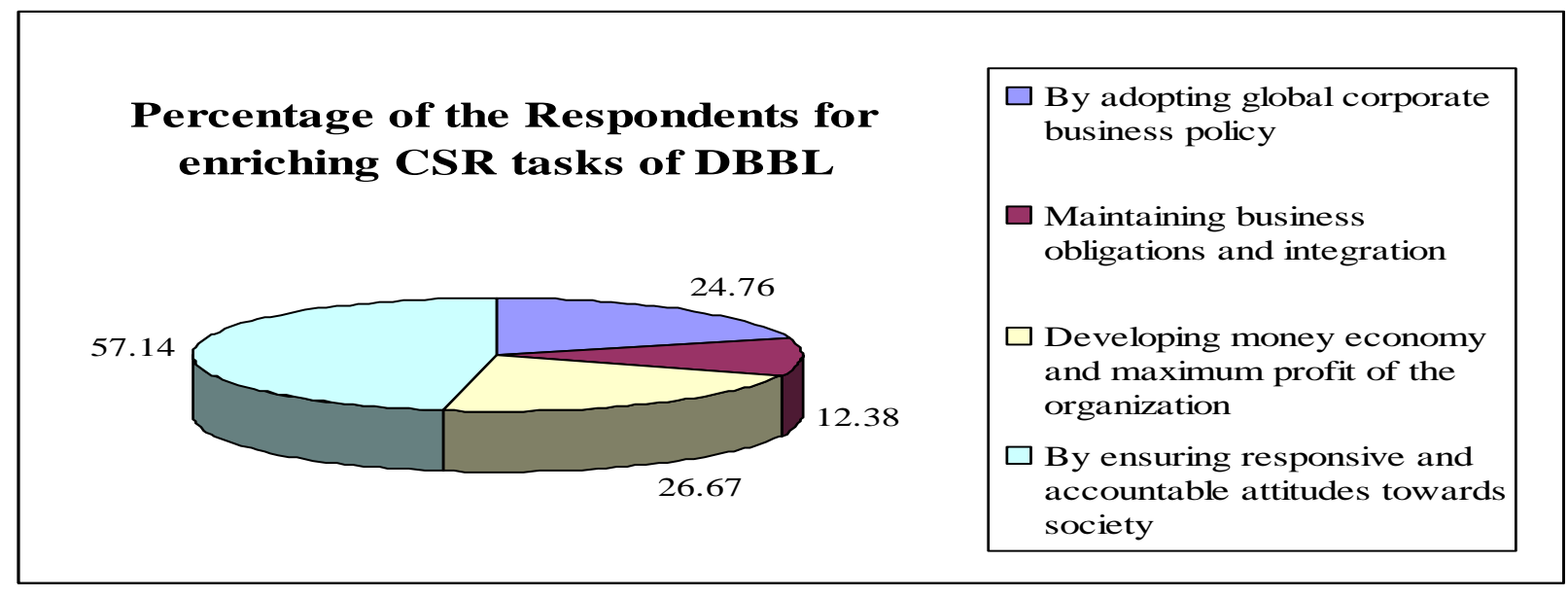

Figure-6: Perception of Respondents for enriching CSR

The above figure demonstrates that (57.14\%) respondents mention that Dutch Bangla Bank Limited can develop its CSR tasks by ensuring responsive and accountable attitudes towards the society. On the other hand, $(26.67 \%)$ of the respondents informed that by developing money economy and maximum profit of their organization CSR tasks possibly will enrich. However, only $12.38 \%$ respondents believe that Dutch Bangla Bank Limited may improve its CSR by maintaining business obligations and integration into the society. Figure-7 illustrates the expectation of the respondents in terms of various sectors which should be incorporated into DBBL current CSR policy. When asked which sectors should be included in the DBBL CSR policy, most respondents $(42 \%)$ pointed that there is an urgent need in improving 'development of traffic management system' in urban areas, particularly in Dhaka city whereas $37.14 \%$ respondents argued for incorporating a tool for "combating against corruption" for ensuring sound and sustainable development of the country. 


\section{Various Sectors which should Incorporate in DBBL Current CSR Policy $(n=105)$}

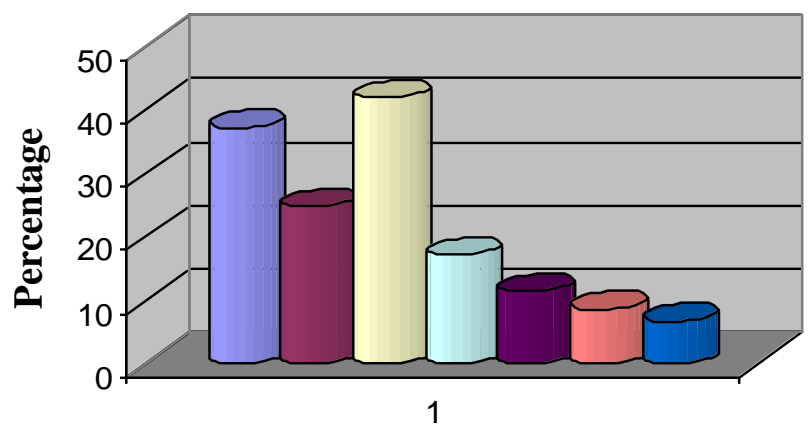

Level of Various Sectors $\square$ Combating against corruption

$\square$ Anti-drug campaign

$\square$ Traffic management development

$\square$ Tree plantation

$\square$ Development of slum people

$\square$ Cleanness of City

$\square$ Gender development

\section{Figure-7: Sectors which should incorporate in DBBL current CSR Policy}

It has also been revealed from this survey that $24.76 \%$ respondents think that 'anti-drug campaign' should be incorporated into present CSR policy of DBBL whereas $6.67 \%$ respondents said that "gender development" should be a part of CSR policy. Many respondents further argued that Ducth Bangla Bank Limited should incorporate tree plantation, improving the lives of the slum dwellers, help keep Dhaka city clean in its CSR policy.

\section{Conclusion}

This study has reinforced the idea that corporate organizations have a greater role to bring about the closer relationship between corporations and the society. Through CSR activities corporate organizations can carry out social and philanthropic activities for furthering equitable and sustainable social development. This study has found out that CSR activities so far are merely implemented for maintaining business policy without really fostering social and benevolent intentions and social responsibility. Many commitments and obligations are only in black and white without really implementing at the grassroots level and there is a demonstrated gap between the rhetoric and realities of CSR activities. Lack of such commitment has in fact resulted into failure of the CSR activities to bring about its comprehensive, effective and potential contribution. Most corporate organizations, including DBBL in Bangladesh, practice CSR because of their business enlargement or for promoting organizational image and recognition. Although CSR activities have a high potential for societal contribution, so far there has been a very little contribution towards family, society and the nation. Needless to say that DBBL has a demonstrated significant contribution to the education, health and safety, environment and disaster management and infrastructure and sports sector. However, such contribution is just a tip on the iceberg as many other big organizations are not coming forward to play their part. 


\section{Macrothink}

Journal of Public Administration and Governance ISSN 2161-7104 2012, Vol. 2, No. 1

This study has further urged for a more social commitment and accountability of the big corporations for more productive and innovative CSR tasks in Bangladesh. As has been demonstrated there can be many other sectors such as traffic management development system, combating against corruption, anti-drug campaign; tree plantation activities which can be incorporated into the current CSR policies of the corporate organizations. This study has thus renewed the call for the corporate organizations to be more proactive, committed and faithful in contributing against many odds of the society. The expectations of the common people must be reflected in the CSR policy. Only a rhetoric commitment of CSR without any real compulsion from inside the corporate organizations would simply lead towards failure of a rather potential channel for social development.

\section{References}

Alam, S. M. (2010) Corporate Social Responsibility (CSR) of MNCs in Bangladesh: A case study on Grameen Phone Ltd. Journal of Potuakhali University of Science and Technology, Vol. 2: 112-127.

Backman, J. (1975) Social responsibility and accountability. New York: New York University Press.

Bangladesh Bank (2010) Review of Corporate Social Responsibility (CSR) Initiatives in Banks 2008 \& 2009. Dhaka: Bangladesh Bank.

Bansal, P. \& Roth, R. (2000) Why Companies Go Green: A model of Ecological Responsiveness. The Academy of Management Journal, Vol. 43(4): 717-736.

Carroll, A. (1979) A three-dimensional conceptual model of corporate social performance. Academy of Management Review, Vol. 4 (4): 496-503.

Carroll, A. B. (1999) Corporate Social Responsibility. Business \& Society, Vol-38(3): 268-295.

Corporate Social Responsibility (CSR) report, DBBL; 2008. Accessed at http://www.dutchbanglabank.com/investor_relations/Annual_Report_2008\%5CPDFs\%5Ccor porate_social_responsibility.pdf

Corporate Social Responsibility of Dutch Bangla Bank. Accessed from http://www.scribd.com/doc/23614359/DBBL-Case-Study-of-CSR

Davis, K. \& Blomstrom, R. (1971) Business, society and environment: Social power and social response. New York: McGraw-Hill.

Eells, R. \& Walton, C. (1974) Conceptual foundations of Business. Burr Ridge, IL: Irwin; 1974: 247 
Epstein, E.M. (1983) The corporate social policy process: Beyond business ethics, Corporate Social Responsibility, and Corporate Social Responsiveness. California Management Review, Vol. 29: 104-119

Howard R. (1953) Social Responsibility of Businessman. New York: Harper \& Raw.

Jones, T. (1980) Corporate Social Responsibility revisited, redefined. California Management Review, Vol. 2: 59-60.

Preston, L. \& Post, J. (1975) Private Management and Public Policy. Englewood Cliffs, NJ: Prentice Hall

Saiful, Islam M. (2004) "Who Benefits, How Benefits": The Political Economy of Grameen Bank's Microcredit Programme in Rural Bangladesh. Oriental Anthropologists, Vol. 4 (1):1-17.

Saiful, Islam M. (2010) Indigenous People, NGOs and the Politics of Alternative Development Discourse in Bangladesh. Dhaka University Journal of Development Studies, Vol. 1: 79-89.

Sethi, S. P. (1975) Dimensions of corporate social performance - An analytical framework. California Management Review, Vol. 17: 58-64.

Walton, C. C. (1967) Corporate Social Responsibilities. Belmont, CA: Wadsworth.

Wood, D. (1991) Corporate Social Performance Revisited. The Academy of Management Review, Vol. 16(4): 691-718. 